\title{
Phoma Leaf Spot Susceptibility and Horticultural Characteristics of Table Beet Cultivars in New York
}

\author{
Lori B. Koenick, ${ }^{1}$ Julie R. Kikkert, ${ }^{2}$ and Sarah J. Pethybridge ${ }^{1,+}$ \\ ${ }^{1}$ Plant Pathology and Plant-Microbe Biology Section, School of Integrative Plant Science, Cornell AgriTech at the New York State Agricultural \\ Experiment Station, Cornell University, Geneva, NY 14456 \\ ${ }^{2}$ Cornell Cooperative Extension, Canandaigua, NY 14424
}

Accepted for publication 28 March 2019.

\section{Abstract}

Phoma leaf spot (PLS), caused by Phoma betae (syn. Neocamarosporium betae), is an important fungal disease affecting table beet (Beta vulgaris L. subsp. vulgaris) production in New York. PLS lesions on the foliage can lead to rejection in fresh market sales and can reduce leaf integrity, which can disrupt mechanized harvesting. Eight popular table beet cultivars were assessed for susceptibility to PLS using $P$. betae isolates representative of the New York population in two small-plot, replicated field trials in Geneva and Freeville, NY. There were significant differences in PLS incidence, severity, and epidemic progress (as measured by area under the disease progress stairs) and horticultural characteristics among cultivars. Non-red table beet cultivars (Avalanche, Boldor, and Chioggia Guardsmark) were less susceptible to PLS than red cultivars (Falcon, Merlin, Rhonda, Red Ace, and Ruby Queen). Significant differences in fresh weight of roots and dry weight of foliage were detected between cultivars at harvest (86 days after planting [DAP] in Freeville and 91 DAP in Geneva). Falcon had significantly higher root weight than Boldor, and Ruby Queen produced significantly more foliage than Boldor. Information on the performance of these cultivars provides locally valuable information for cultivar selection in a broad range of markets.

Keywords: cultural practices, vegetables, fungal disease
New York (NY) is currently the second largest producer of table beet (Beta vulgaris L. subsp. vulgaris) in the United States, representing $26 \%$ of that grown in 2012 (USDA-NASS 2012). Recently, there has been an expansion in table beet production owing to an increased awareness by consumers of the potential health benefits of consumption (Clifford et al. 2017; Navazio et al. 2010; Pethybridge et al. 2018). Table beets are grown in NY for processing into cans and jars, fresh market sales of roots and/or foliage, and use in value-added products such as juices and powders (Pethybridge et al. 2018). For processing, root size, shape, texture, uniformity, flavor, color, and quality are important cultivar characteristics (Goldman and Navazio 2003; Kikkert et al. 2010; Pethybridge et al. 2018; USDA 2017). Root and foliage characteristics are also important for fresh market sales yet can be more diverse in color and appearance to appeal to a broader consumer base.

Disease management is critical to ensuring profitability and productivity of table beet production (Abawi et al. 1986; Kikkert

${ }^{\dagger}$ Corresponding author: S. J. Pethybridge; E-mail: sjp277@ cornell.edu

Funding: L. B. Koenick was supported in part by a fellowship from the Cornell Graduate School. This research was supported by the Towards Sustainability Foundation Organic and Sustainability Grants Program (2017/18), and United States Department of Agriculture, National Institute of Food and Agriculture Hatch project NYG-625-424, managed by the New York State Agricultural Experiment Station (NYSAES), Cornell University, NY.

The author(s) declare no conflict of interest.

(C) 2019 The American Phytopathological Society et al. 2010; Pethybridge et al. 2018; Shah and Stivers-Young 2004). One of the most important foliar diseases is Phoma leaf spot (PLS), caused by the fungus, Phoma betae (syn. Neocamarosporium betae) (Ariyawansa et al. 2015), which can cause loss of green leaf area, deleteriously affecting root yield and quality (Pool and McKay 1915). On foliage, PLS symptoms are tan-brown lesions with light brown centers and dark concentric rings (Fig. 1) (Harveson et al. 2009; Pool and McKay 1915). At crop emergence, P. betae can cause pre- and post-emergence damping-off, which can negatively affect crop stands (Edson 1915; Pethybridge et al. 2018). On roots, $P$. betae can cause Phoma root rot, which manifests as dry, black necrotic lesions usually beginning at the crown (Harveson et al. 2009). Latent infection of roots can lead to substantial losses from decay in storage (Bugbee 1982; Pethybridge et al. 2018). In NY, surveys detected PLS in 35 of 60 table beet fields in 2017 and 2018. Moreover, the prevalence of PLS was higher in fields grown using organic production practices (74\%) than conventional techniques (49\%) (Koenick and Pethybridge, unpublished data).

$P$. betae is commonly introduced to fields through infected seed (Edson 1915; Herr 1971; Leach and MacDonald 1976; Mangan 1971) and can overwinter in soil on plant debris for up to 26 months (Bugbee and Soine 1974). During the cropping season, P. betae undergoes asexual reproduction, producing pycnidia, and the resulting conidia can be dispersed short distances via water splash (Harveson et al. 2009; Monte and García-Acha 1988). Although the sexual form has not been observed in NY (Pethybridge, unpublished data), $P$. betae is capable of sexual reproduction, producing pseudothecia and ascospores that can be disseminated long distances via wind (Bugbee 1979). Koenick et al. (2019) found 
$P$. betae to be heterothallic and molecular evidence for NY populations of $P$. betae to use a mixed reproductive mode throughout the growing season. Genetic differentiation and population structure among NY populations and those from Washington state supported within-field and external inoculum sources to influence PLS epidemics (Koenick et al. 2019). Quantifying the temporal progression of a disease can also enhance our understanding of the relative importance of different inoculum sources and the various options, such as cultivar susceptibility, for improving disease management strategies (Jeger 2004; Madden et al. 2007; Vanderplank 1963).
Disease management in conventional table beet production is often reliant upon multiple applications of fungicides (Pethybridge et al. 2018; Vaghefi et al. 2016). If best management guidelines are not used, reliance on fungicides may not be sustainable owing to the potential for development of resistance to those with single-site modes of action (Brent and Hollomon 2007). For organic table beet production, the inability to use conventional fungicides makes cultural strategies, such as crop rotation, field design manipulation, and cultivar selection, critical for effective disease management (Shah and Stivers-Young 2004). These strategies are also beneficial to ensure horticultural characteristics, such as root size and shape,

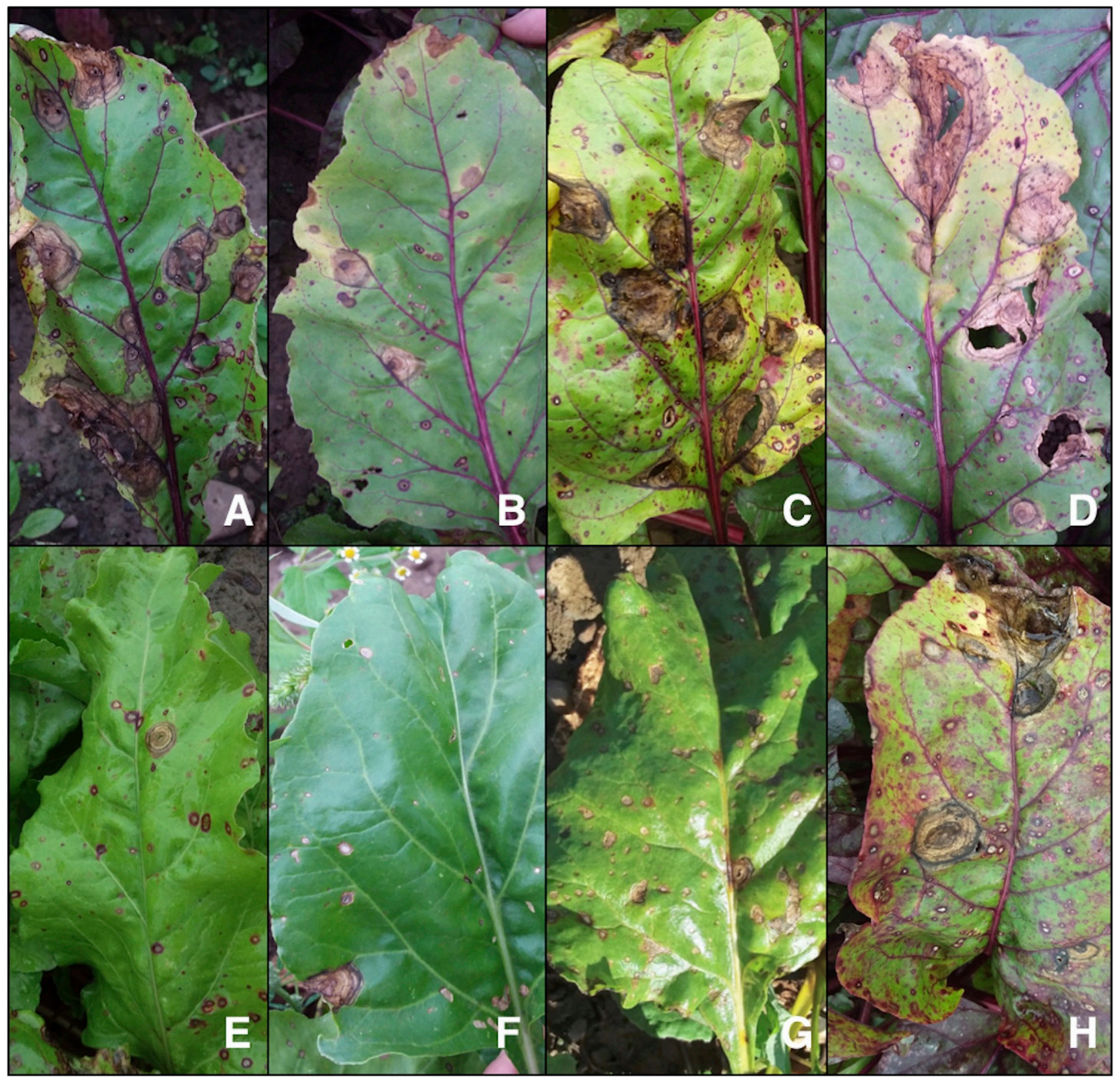

FIGURE 1

Phoma leaf spot symptoms caused by Phoma betae on different table beet cultivars within two replicated field trials conducted in New York in 2018: A, Rhonda; B, Red Ace; C, Merlin; D, Falcon; E, Chioggia Guardsmark; F, Avalanche; G, Boldor; and H, Ruby Queen. 
meet market requirements (Clark et al. 1967; Kikkert et al. 2010). The processing industry dictates acceptable table beet root size and shape to enable fit into cans and jars (USDA 2017), resulting in the use of only a few cultivars. For the fresh market, there is more flexibility in cultivar selection, and hence there is potential to select cultivars that are less susceptible to disease. Variations in the susceptibility of selected table beet cultivars have been quantified for Cercospora leaf spot caused by Cercospora beticola (Pethybridge et al. 2017a) and other diseases of sugar beet (Smith and Martin 1978). In organic production systems, the selection of cultivars with enhanced disease resistance may also reduce the use of copper, lessening build-up in soil and the potential for plant damage from phytotoxicity resulting from interactions at high temperatures (Pethybridge et al. 2017a, 2017b). To the best of our knowledge, no information on the susceptibility of table beet cultivars to PLS is available. The objectives of this study were to evaluate PLS susceptibility of popular table beet cultivars and characterize important horticultural characteristics under NY growing conditions.

\section{Field Trial Design and Weather}

The susceptibility of eight table beet cultivars (Avalanche, Boldor, Chioggia Guardsmark, Falcon, Merlin, Rhonda, Red Ace, and Ruby Queen) to infection by P. betae was assessed in two small-plot, replicated field trials in 2018. Cultivars were selected based on popularity of use in NY small, mixed-vegetable farms and to encompass a broad range of end uses and root characteristics (Table 1). Commercial seed lots were used; seed companies and treatments are listed in Table 1. Notably, Boldor seeds were untreated, Rhonda seeds had a proprietary organic film coat, and seeds of other cultivars were fungicide treated.

The location of one field trial was at the Homer C. Thompson Research Farm (Freeville, NY; $42.52^{\circ} \mathrm{N}, 76.34^{\circ} \mathrm{W}$ ), and the second trial was at the Research North Farm of Cornell AgriTech at The New York State Agricultural Experiment Station (Geneva, NY; $42.87^{\circ} \mathrm{N}, 77.03^{\circ} \mathrm{W}$ ). The soil type at Freeville was a Howard gravel loam. The soil type at Geneva was a Lima silt loam.

Each trial was planted using an identical randomized block design, and each cultivar was replicated five times. In Freeville, a plot consisted of four rows $(38 \mathrm{~cm}$ between individual rows and $4.6 \mathrm{~m}$ long). There were four unplanted buffer rows between plots and a $\sim 1.5-\mathrm{m}$ unplanted alley between plots within rows, which were cultivated for weed control as needed. In Geneva, a plot consisted of two rows ( $76.2 \mathrm{~cm}$ between individual rows), each $4.6 \mathrm{~m}$ long. Two buffer rows of Ruby Queen separated plots among rows, and there was a $\sim 1.5$-m unplanted alley between plots within rows.

The trial at Freeville was planted on June 12, 2018, with a Monosem vacuum planter (Monosem, Edwardsville, KS) at an inrow planting density of 56.1 seeds $/ \mathrm{m}$. The trial at Geneva was planted on June 21, 2018, with a Jang JP1 clean seeder (Jang Automation, Cheongju, South Korea) at an in-row plant density of 30.4 seeds $/ \mathrm{m}$. In Freeville, $560.43 \mathrm{~kg} / \mathrm{ha}$ of $20 \mathrm{~N}-10 \mathrm{P}-10 \mathrm{~K}$ fertilizer (Phelps Supply, Phelps, NY) was broadcast applied and shallow incorporated prior to planting and S-metolachlor herbicide (Dual Magnum, Syngenta Corp., Greensboro, NC) applied at 0.78 liter/ha on the same day as planting. At 51 days after planting (DAP), an application of spinosad insecticide (0.58 liter/ha; Entrust SC, Dow AgroSciences, Indianapolis, IN) with an adjuvant $(0.04 \% \mathrm{v} / \mathrm{v}$; Induce, Helena Agri-Enterprises, Collierville, TN) was made for leaf miner control. Ammonium nitrate $(22.7 \mathrm{~kg} / \mathrm{ha}$; Phelps Supply) was side dressed by hand at 49 DAP.

In Geneva, 10N-5P-10K plus boron at $2.2 \mathrm{~kg} / \mathrm{ha}$ (Phelps Supply) was broadcast at $336.26 \mathrm{~kg} / \mathrm{ha}$ prior to planting and banded at $392.3 \mathrm{~kg} / \mathrm{ha}$ during planting. The herbicide S-metolachlor ( 0.78 liter/ha) was applied on the same day as planting. Both trials were irrigated as needed to maintain optimal plant growth and disease development.

Weather. On-site average monthly temperature and precipitation data for both field locations were obtained from the Northeast Regional Climate Center (http://climod2.nrcc.cornell.edu/). Data at each location were compared with the long-term averages (LTA) (1981 to 2010) (Northeast Regional Climate Center 2018). Growing degree days $\left(\mathrm{GDD}_{10}\right)$ calculated with a base of $10^{\circ} \mathrm{C}$ were also obtained from the Northeast Regional Climate Center and compared with the LTA.

Weather during the growing seasons in Geneva and Freeville was similar to the LTA. At Geneva, the average minimum and maximum temperatures were 12.9 and $23.5^{\circ} \mathrm{C}$ (June), 16.7 and $27.8^{\circ} \mathrm{C}$ (July), 17.4 and $26.1{ }^{\circ} \mathrm{C}$ (August), and 13.2 and $22.8^{\circ} \mathrm{C}$ (September). At Freeville, the average minimum and maximum temperatures were 11.3 and $23.2^{\circ} \mathrm{C}$ (June), 15.2 and $27.8^{\circ} \mathrm{C}$ (July), 16.6 and $25.9^{\circ} \mathrm{C}$ (August), and 12.9 and $22.8^{\circ} \mathrm{C}$ (September). Temperatures were less than $10 \%$ different than the LTA in both locations, with

\begin{tabular}{|c|c|c|c|c|c|c|}
\hline \multicolumn{7}{|c|}{$\begin{array}{c}\text { TABLE } 1 \\
\text { Characteristics of cultivars evaluated for susceptibility to Phoma leaf spot caused by Phoma betae in replicated field trials } \\
\text { in New York in } 2018\end{array}$} \\
\hline Cultivar & Color & Root shape & Primary use ${ }^{w}$ & Time to maturity (days) ${ }^{\mathbf{x}}$ & Seed companyy (city, state) & Seed treatment $\mathbf{t}^{\mathbf{z}}$ \\
\hline Avalanche & White & Globe & $\mathrm{FM}$ & 55 & Harris Seeds (Rochester, NY) & $\mathrm{M}, \mathrm{T}, \mathrm{F}$ \\
\hline Boldor & Yellow & Globe & $\mathrm{FM}$ & 55 & Johnny's Seeds (Fairfield, ME) & Untreated \\
\hline $\begin{array}{l}\text { Chioggia } \\
\text { Guardsmark }\end{array}$ & $\begin{array}{l}\text { Pink and } \\
\text { white } \\
\text { striped }\end{array}$ & Globe & $\mathrm{FM}$ & 55 & Sakata (Morgan Hill, CA) & $\mathrm{M}, \mathrm{T}, \mathrm{F}$ \\
\hline Falcon & Red & Blocky & $\mathrm{FM}$ & $80-85$ & Sakata (Morgan Hill, CA) & $\mathrm{M}, \mathrm{T}$ \\
\hline Merlin & Red & Globe & $\mathrm{FM}$ & 48 & Harris Seeds (Rochester, NY) & $\mathrm{M}, \mathrm{T}$ \\
\hline Red Ace & Red & Globe & $\mathrm{P}$ and $\mathrm{FM}$ & 50 & Harris Seeds (Rochester, NY) & $\mathrm{M}, \mathrm{T}$ \\
\hline Rhonda & Red & Globe & FM & $65-70$ & Bejo (Geneva, NY) & Organic treatment \\
\hline Ruby Queen & Red & Globe & $\mathrm{P}$ & 55 & Seneca Foods (Geneva, NY) & $\mathrm{T}$ \\
\hline
\end{tabular}

${ }^{\mathrm{w}} \mathrm{FM}=$ fresh market, and $\mathrm{P}=$ processing.

${ }^{\mathrm{x}}$ From direct seeding to harvest.

${ }^{\mathrm{y}}$ Company is where seeds were obtained and are not necessarily the breeder of the cultivar.

${ }^{\mathrm{z}} \mathrm{M}=$ mefenoxam; $\mathrm{T}=$ thiram; and $\mathrm{F}=$ fludioxonil. 
the only exceptions being minimum temperatures in August and September. In both locations, August and September minimum temperatures were up to $12 \%$ higher compared with the LTA. The average monthly rainfall was $6.9 \mathrm{~cm}$ (June), $8.1 \mathrm{~cm}$ (July), $17 \mathrm{~cm}$ (August), and $8.7 \mathrm{~cm}$ (September) at Geneva; and $4.9 \mathrm{~cm}$ (June), $17.7 \mathrm{~cm}$ (July), $11.3 \mathrm{~cm}$ (August), and $13.1 \mathrm{~cm}$ (September) at Freeville. The cropping season was wetter with a 14 and $15 \%$ increase in total precipitation for June through September compared with the LTA in Geneva and Freeville, respectively. A total of 2,246 $\mathrm{GDD}_{10}$ accumulated during the growing season in Geneva (LTA = 2,052) and 2,111 $\mathrm{GDD}_{10}$ accumulated in Freeville (LTA $=1,880$ ).

Preparation and application of $\boldsymbol{P}$. betae inoculum. The entire trial area was inoculated at 42 DAP (Geneva) and 56 DAP (Freeville), when plants had 10 to 15 true leaves. P. betae isolates collected in NY from diseased table beet leaves (RN1, RN20, TR1, and TR30) were used to prepare conidial inoculum. No information is available on differences in virulence and aggressiveness among $P$. betae isolates in the NY population. However, the high genetic diversity typically observed in $P$. betae populations suggests that differences in virulence may be likely (Koenick et al. 2019), and hence a mixed inoculum of representative isolates was preferred for these trials.

Inoculum was prepared by removing the isolates from long-term storage $\left(-20^{\circ} \mathrm{C}\right)$ and subculturing onto clarified V8 (CV8) juice (10\% [v/v] CV8 juice [Campbell's Soup Co., Camden, NJ], 0.5\% [w/v] $\mathrm{CaCO}_{3}$ ) agar (Jeffers 2015; Miller 1955). After 5 to 7 days of growth, each plate was subcultured onto four new CV8 plates and incubated for 14 days in a 12-h photoperiod at room temperature to induce sporulation. Sterile distilled water $(5 \mathrm{ml})$ was added to each plate, and a scalpel was used to dislodge pycnidia into a falcon tube with $20 \mathrm{ml}$ of sterile distilled water. The falcon tube was vigorously vortexed, and the solution was passed through two layers of sterile muslin cloth into a new suspension. A hemocytometer was used to quantify conidial concentration in the resulting suspension. The concentration of the inoculum was $7 \times 10^{4}$ conidia/ml (Geneva) and $4 \times 10^{4}$ conidia/ml (Freeville) with $0.1 \%(\mathrm{v} / \mathrm{v})$ polysorbate 20 (Tween-20, Agdia, Elkhart, IN) added before application. To quantify germination efficiency, $100 \mu \mathrm{l}$ of the suspension was spread over the surface of three 2\% water agar (Difco Agar, Becton, Dickinson and Company, Sparks, MD) plates. After $24 \mathrm{~h}$, the germination of 100 arbitrarily selected conidia was evaluated at 63× magnification (Olympus SZX10 Zoom Stereo Microscope, Olympus, Tokyo, Japan). A conidium was considered germinated if the germ tube was at least twice the length of the conidium. Germination efficiency of the conidia was 98 and $97 \%$ for the Geneva and Freeville trials, respectively.

For each trial, 6 liters of inoculum $(+0.1 \%$ v/v polysorbate 20$)$ was applied within $5 \mathrm{~h}$ of preparation. The inoculum was applied with a backpack sprayer (DB Sprayer Professional, Fountainhead Group, New York Mills, NY) at a rate of $8.2 \mathrm{ml} / \mathrm{m}$ with a walking speed of $1.67 \mathrm{~s} / \mathrm{m}$.

Evaluating for disease and yield characteristics. In-row plant density counts (number of plants/m) were conducted at 28 DAP at both locations following stabilization of plant stands. PLS incidence and severity were assessed on 10 arbitrarily selected leaves from each of two rows (20 leaves per plot) and averaged on a per plot basis. Incidence was defined as the number of leaves with at least one PLS lesion divided by 20 leaves multiplied by 100 . Severity was defined as the percentage of symptomatic area relative to total leaf area and averaged per plot. In Freeville, leaves were only selected from the middle two rows of each plot. Disease assessments were conducted at least six times throughout the growing season. In Freeville, assessments were made at 0 (August 3), 8 (August 15), 12 (August 19), 15 (August 22), 22 (August 29), and
28 (September 5) days postinoculation (DPI). In Geneva, assessments were made at 0 (August 2), 8 (August 8), 13 (August 15), 16 (August 18), 20 (August 22), 26 (August 28), 32 (September 4), 39 (September 11), and 46 (September 18) DPI. Disease assessments were recorded on a tablet using the Android application Field Book (Rife and Poland 2014).

Trials were harvested by hand at 86 DAP (Freeville) and 91 DAP (Geneva). Plants were removed from two 0.5-m transects within each plot and separated into foliage and roots. The fresh weight of foliage $(\mathrm{kg})$ was recorded in the field. A subsample of the foliage was weighed and dried at $37.5^{\circ} \mathrm{C}$ for 4 days to calculate percent dry matter. The roots from each plot were counted and weighed $(\mathrm{kg})$. A subsample of up to 20 roots was randomly selected from each plot for measurement of root diameter $(\mathrm{mm})$ with electronic calipers. When less than 20 roots were harvested from each plot, the shoulder diameter of all roots was measured.

\section{Data Analysis}

All statistical analyses were performed in R statistical software version 3.5.1 ( $\mathrm{R}$ Core Team 2017). Disease severity at each evaluation was used to calculate the area under the disease progress stairs (AUDPS) as a measure of epidemic progression (Simko and Piepho 2012). First, the area under the disease progress curve (AUDPC) was calculated in the R package agricolae version 1.2-8 (De Mendiburu 2017), and then it was converted to AUDPS using the following formula (Simko and Piepho 2012):

$$
\mathrm{AUDPS}=\mathrm{AUDPC}+\left(\frac{y_{1}+y_{n}}{2} \times \frac{D}{n-1}\right)
$$

Effect of cultivar. The R package lme 4 version 1.18 (Bates et al. 2015) was used to create mixed models with table beet cultivar as a fixed effect and replication as a random effect. The effect of cultivar on PLS incidence, severity, and AUDPS was evaluated through analysis of variance (ANOVA). To check assumptions of normality and homoscedasticity, quantile-quantile plots (Atkinson 1987), histograms with a normality curve overlaid, and residual plots were evaluated visually in the $\mathrm{R}$ packages car version 3.0-2 (Fox and Weisberg 2011), rcompanion version 2.0.0 (Mangiafico 2018), and ggplot2 version 3.1.0 (Wickham 2016), respectively. When necessary, the Shapiro-Wilk test (Shapiro and Wilk 1965) was conducted in the R package stats version 3.6.0 (R Core Team 2017) as another formal test of normality. Outliers were checked with Cook's distance (Cook and Weisberg 1982) in stats. Transformations were made as needed. Data for root number in the Geneva field trial benefited from a log transformation, and AUDPS (Freeville field trial) required a square-root transformation to remove skew and comply with ANOVA assumptions.

The effect of plant density as a covariate on disease and yield component response variables was assessed using ANOVA and included in models when significant $(P<0.05)$. Significant differences $(P=0.05)$ in the means between cultivars in each trial were identified using the Tukey-Kramer honestly significant difference method (Miller 1981) in the R package emmeans version 1.3.0 (Lenth et al. 2018). Data for each field trial were analyzed separately.

Temporal disease progress. Temporal analysis of epidemics was conducted using PROC REG (SAS version 9.4, SAS Institute, Cary, NC). Disease progression was fit to exponential, monomolecular, logistic, and Gompertz models for each field trial. Disease epidemics may be classified as monocyclic (one infection cycle per crop cycle) or polycyclic (multiple infection cycles per crop cycle) 
(Madden et al. 2007; Vanderplank 1963). A monomolecular model is usually the best fit of a monocyclic epidemic, whereas Gompertz and logistic models are usually the best descriptors of a polycyclic epidemic (Madden et al. 2007). Goodness of each model fit was determined by examining residual plots for normality, randomness, and constant variance and by viewing the following fitness statistics for linearity: $F$ statistic, coefficient of determination $\left(R^{2}\right)$, the root mean square error (RMSE), and coefficient of variation (CV). Comparisons between models were conducted by calculating the back-transformed fitted $\left(R^{* 2}\right)$ severity values of the original. Within each cultivar, fit of the selected model was summarized using the $R^{* 2}$, RMSE, CV, and slope and intercept values.

\section{Cultivar Susceptibility to PLS}

Symptoms of PLS were typical tan-brown lesions with dark concentric rings of pycnidia and similar across table beet cultivars (Fig. 1). Significant differences in PLS susceptibility and horticultural characteristics were observed among cultivars at both locations. Cultivar had a significant effect on in-row plant density at both locations (Table 2) and was a significant covariate for root diameter and average root weight at Geneva but did not influence response variables at Freeville.

Differences in PLS incidence, severity, and progression were also observed among cultivars. Non-red cultivars had significantly lower PLS incidence than red cultivars (Table 2). At Geneva, on average, PLS incidence was 47.3 and $86 \%$ in non-red and red cultivars, respectively, at the final assessment. In Freeville, PLS incidence was lowest in Chioggia Guardsmark and Boldor with an average of $29.5 \%$. PLS incidence was significantly higher in red than non-red cultivars with an average of $77.2 \%$ (Table 2).

At the final assessment, PLS severity was lowest in Chioggia Guardsmark in both trials (7.9 and 5\% in Geneva and Freeville, respectively). In contrast, PLS severity was highest in Rhonda in both trials and was significantly different from all cultivars except Falcon at Geneva. PLS severity in Rhonda was 342 and $862 \%$ higher than in Chioggia Guardsmark at Geneva and Freeville, respectively. Of the red cultivars, final PLS severity was not significantly different between Red Ace, Falcon, Merlin, and Ruby
Queen in both trials (Table 2). PLS severity in Red Ace was 48.5 and $123.7 \%$ less than in Rhonda at Geneva and Freeville, respectively. Similar trends in PLS susceptibility were observed among non-red and red cultivars when evaluating AUDPS (Fig. 2; Table 2). AUDPS was significantly lower in non-red cultivars than red cultivars at Geneva. Chioggia Guardsmark and Boldor had the lowest AUDPS values at Freeville, and AUDPS values were not significantly different among Falcon, Merlin, Red Ace, and Ruby Queen in both trials (Table 2). Rhonda had the highest AUDPS values in both trials. Temporal disease progress in Rhonda and Falcon was best fit to a Gompertz model (Table 3).

\section{Horticultural Characteristics of Cultivars}

Significant differences were found among cultivars for all root characteristics at Geneva (Table 4). Ruby Queen produced significantly more roots than other cultivars. Of the red cultivars, Ruby Queen produced 151, 153, 259, and 230\% more roots than Falcon, Merlin, Red Ace, and Rhonda, respectively. Root number was not significantly different between Avalanche, Boldor, Red Ace, and Rhonda (Table 4). At Geneva, Ruby Queen and Chioggia Guardsmark produced smaller roots. Root diameter was not significantly different between Avalanche, Boldor, Falcon, Red Ace, and Rhonda, but these were significantly larger than Ruby Queen. Root weight was significantly higher in Falcon than Ruby Queen at Geneva and than Boldor at both locations. For example, Falcon produced 100 and $107 \%$ more root biomass than Boldor at Geneva and Freeville, respectively. There were no significant differences in root number, root diameter, and average root weight among cultivars at Freeville (Table 4).

Cultivar also had a significant effect on the dry weight of foliage in both trials (Table 4). For example, Boldor produced significantly less foliage than Chioggia Guardsmark and Ruby Queen. At Freeville, Boldor produced significantly less foliage than other cultivars except for Rhonda. The dry weight of foliage was not significantly different between Chioggia Guardsmark, Falcon, Merlin, Red Ace, Rhonda, and Ruby Queen at Freeville and between Avalanche, Chioggia Guardsmark, Falcon, Merlin, Rhonda, and Ruby Queen at Geneva (Table 4).

\begin{tabular}{|c|c|c|c|c|c|c|c|c|}
\hline \multicolumn{9}{|c|}{$\begin{array}{l}\text { TABLE } 2 \\
\text { Effect of table beet cultivar on plant density and the incidence and severity of Phoma leaf spot (PLS) caused by Phoma betae at } \\
\text { harvest, and epidemic progress in two field trials at Geneva and Freeville, NY, in } 2018\end{array}$} \\
\hline Cultivar & \multicolumn{2}{|c|}{ Plant densityw } & \multicolumn{2}{|c|}{ Incidence $(\%)^{x}$} & \multicolumn{2}{|c|}{ Disease severity $(\%)^{x}$} & \multicolumn{2}{|c|}{ AUDPSy } \\
\hline Avalanche & $13.9 a^{z}$ & $27.5 \mathrm{ab}$ & $56 \mathrm{a}$ & $48 \mathrm{~b}$ & $15.3 \mathrm{~b}$ & $14.6 \mathrm{ab}$ & $352.7 \mathrm{~b}$ & $15.2(233.3) b$ \\
\hline Boldor & $8.5 \mathrm{a}$ & $14.7 \mathrm{a}$ & $42 \mathrm{a}$ & $28 \mathrm{a}$ & $10.9 \mathrm{ab}$ & $5.2 \mathrm{a}$ & $264.6 \mathrm{ab}$ & $7.7(60.0) \mathrm{a}$ \\
\hline Merlin & $16.3 \mathrm{bc}$ & $21.1 \mathrm{ab}$ & $87 \mathrm{~b}$ & $76 \mathrm{~cd}$ & $27.0 \mathrm{c}$ & $30.1 \mathrm{c}$ & $599.5 \mathrm{c}$ & $20.7(427.8) \mathrm{c}$ \\
\hline Red Ace & $12.2 \mathrm{ab}$ & $18.4 \mathrm{a}$ & $82 \mathrm{~b}$ & $65 \mathrm{c}$ & $23.5 \mathrm{c}$ & $21.6 \mathrm{bc}$ & $554.1 \mathrm{c}$ & $17.8(318.4) b c$ \\
\hline Rhonda & $14.6 \mathrm{ab}$ & $17 \mathrm{a}$ & $90 \mathrm{~b}$ & $88 \mathrm{~d}$ & $34.9 \mathrm{~d}$ & $48.1 \mathrm{~d}$ & $786.1 \mathrm{~d}$ & $27.0(732.4) \mathrm{d}$ \\
\hline Ruby Queen & $39.4 \mathrm{~d}$ & $29.9 \mathrm{ab}$ & $84 \mathrm{~b}$ & $79 \mathrm{~cd}$ & $26.9 \mathrm{c}$ & $27.8 \mathrm{c}$ & $613.4 \mathrm{c}$ & $19.3(375.4) \mathrm{c}$ \\
\hline HSD & 7.3 & 16.3 & 16 & 15 & 7.11 & 10.61 & 139.52 & 3.58 \\
\hline
\end{tabular}

${ }^{\mathrm{w}}$ In-row plant density counts (number of plants $/ \mathrm{m}$ ) evaluated at 28 days after planting.

${ }^{\mathrm{x}}$ Incidence is the number of leaves with at least one PLS lesion/total number of leaves $\times 100$; severity is the percentage of the leaf affected by PLS relative to the total leaf area.

y Area under the disease progress stairs (Simko and Piepho 2012); nontransformed values are in parentheses.

${ }^{\mathrm{z}}$ Values given are the means of five replicates. Means followed by the same letter in a column are not statistically different using the Tukey-Kramer honestly significant difference (HSD) $(P \leq 0.05)$. 
Study Implications and Conclusions

Maintaining foliar health is essential for profitable table beet production to minimize crop losses through facilitation of mechanized harvest and ensuring high product quality for direct sales (Pethybridge et al. 2018). Strict quality standards make selection of

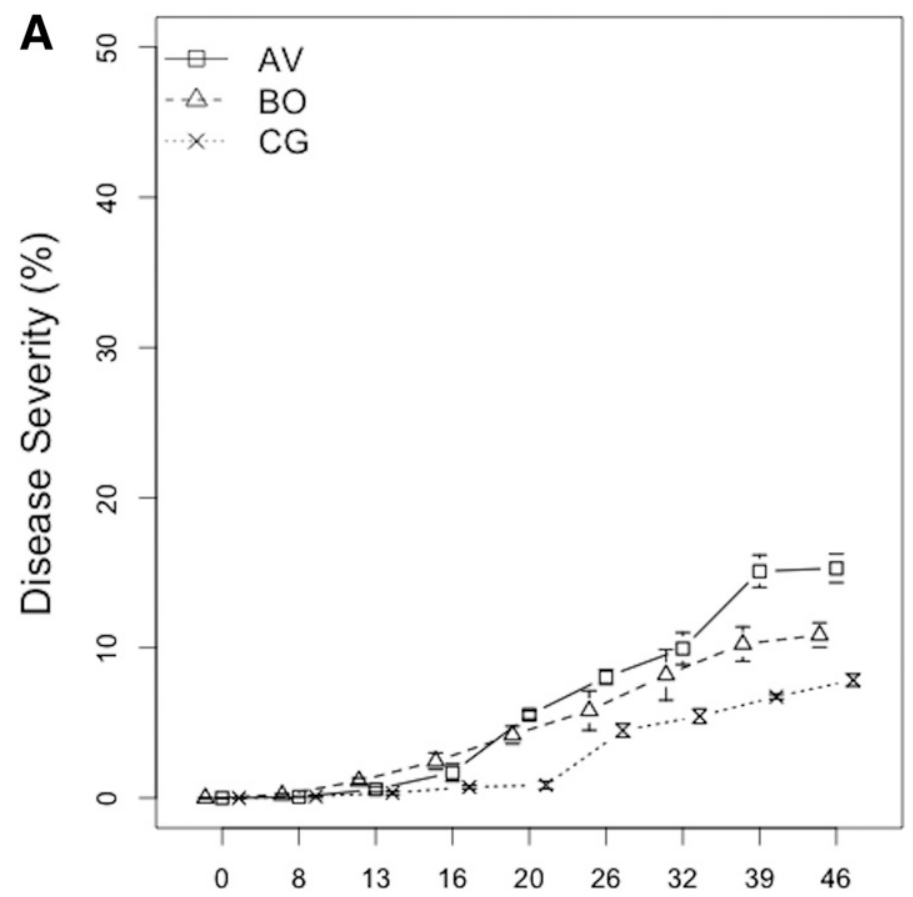

C

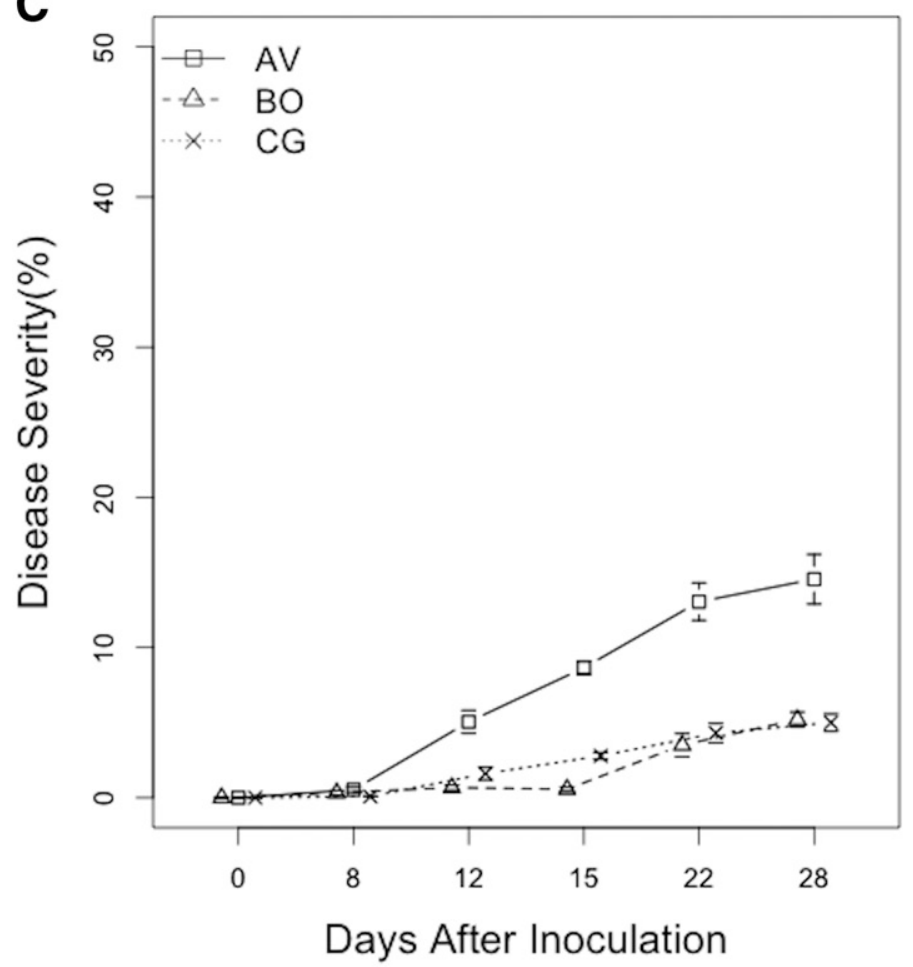

cultivars with varying susceptibility to PLS and other diseases an important tool for disease management. To the best of our knowledge, this is the first study to evaluate the susceptibility of eight popular table beet cultivars to PLS, and results were consistent across trials. Minor differences in disease severity and epidemic

B

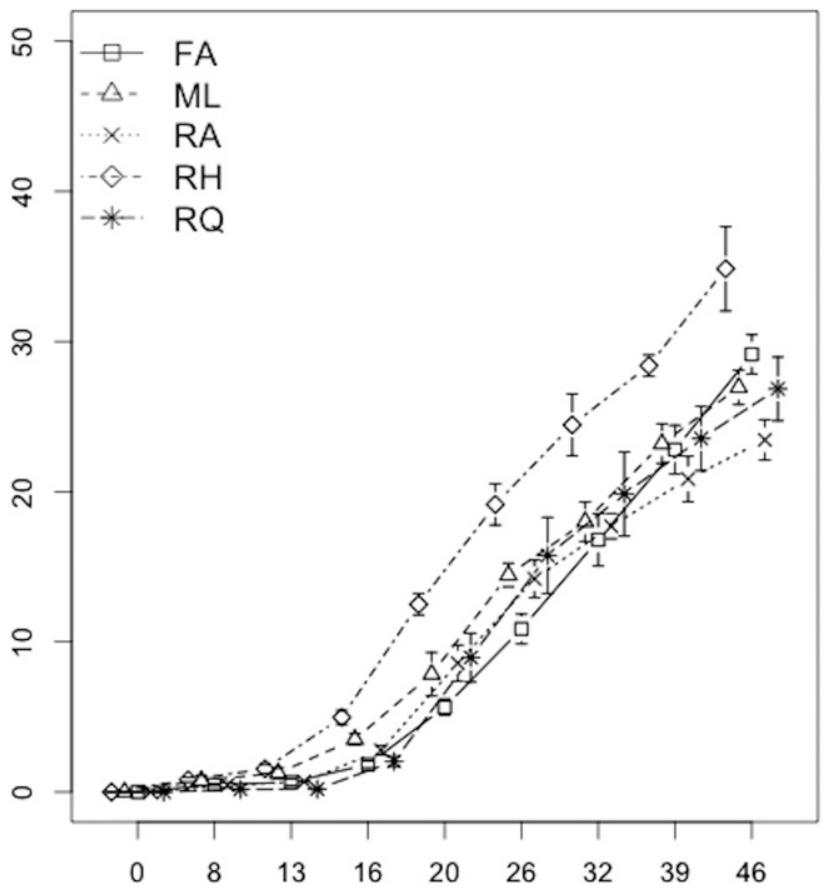

D

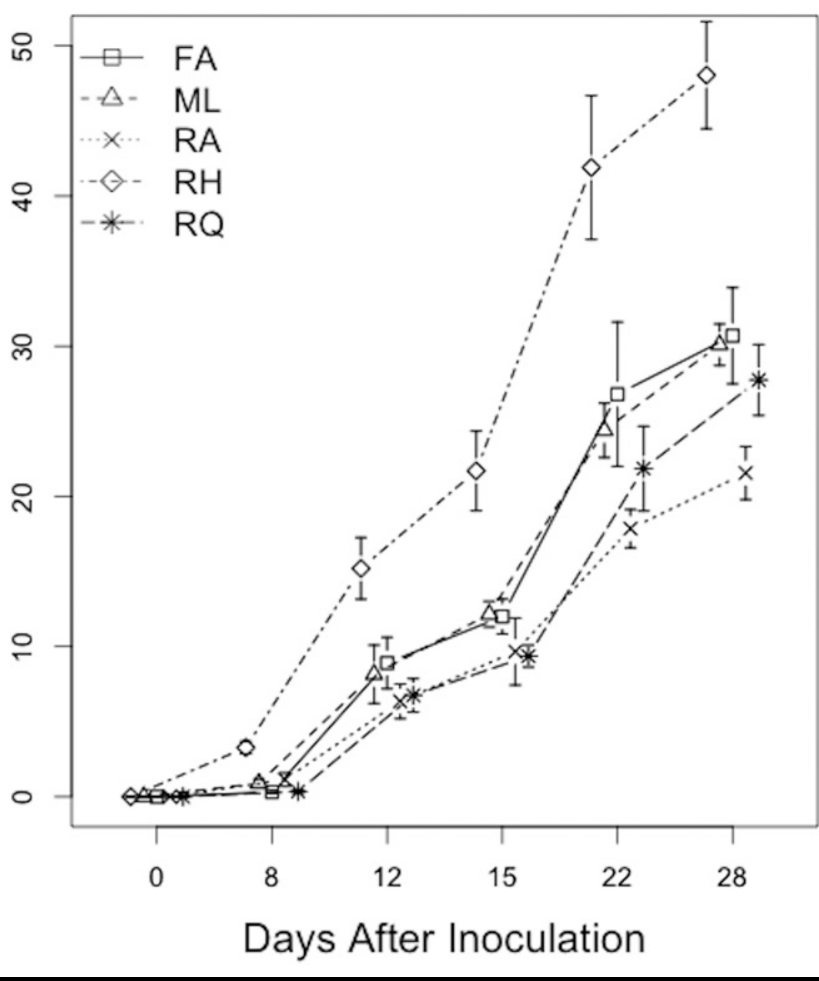

FIGURE 2

Disease progress curves depicting Phoma leaf spot epidemics caused by Phoma betae for non-red and red table beet cultivars at field trials in New York in 2018 : A, non-red, Geneva; B, red, Geneva; C, non-red, Freeville; and D, red, Freeville. AV = Avalanche; BO = Boldor; CG = Chioggia Guardsmark; FA= Falcon; ML = Merlin; $\mathrm{RA}=$ Red Ace; RH = Rhonda; and RQ = Ruby Queen. 
progress between trials may be explained by variation in environmental conditions, plant age, and agronomic factors. However, temperature and rainfall totals and patterns over the cropping season were similar between the locations and the LTA. Some damage from site-specific biotic stresses was incurred and was homogeneous over the trial areas. For example, moderate damage from leaf miner was incurred at Freeville and required an insecticide application.

Owing to machinery differences, row spacing within plots at Freeville was half of that at Geneva. Row spacing can affect final yields, root size, and disease incidence (Kikkert et al. 2010; Shah and Stivers-Young 2004). A survey conducted between 1998 and 2000 found that narrower row spacing increased the incidence of root decay in table beets (Shah and Stivers-Young 2004). Moreover, in general, positive correlations between plant density and disease incidence have been well characterized across many pathosystems (Burdon and Chilvers 1982). Trade-offs between yield components and disease are important to quantify because they may form an integral part of a durable management strategy for foliar disease in table beet.

Higher PLS severity across cultivars at Freeville compared with Geneva could also be attributed to differences in growth stage. Plants were 2 weeks older in Freeville when inoculated than at Geneva. Age has been reported as a factor in the susceptibility of sugar beet to PLS, with older leaves being more susceptible (Pool and McKay 1915). Despite differences in field design and plant age, differences between cultivars in PLS susceptibility were similar among field trials.

In both field trials, non-red cultivars (Avalanche, Boldor, and Chioggia Guardsmark) were less susceptible to PLS than red cultivars (Red Ace, Ruby Queen, Merlin, Rhonda, and Falcon). Betalains, a class of alkaloid pigments, are responsible for color variation in table beet (Goldman and Navazio 2008). Betalains include red-violet betacyanin and yellow betaxanthin pigments, and they convey multiple advantages for plant growth and defense (Georgiev et al. 2008). For example, betalains have been reported as important for attracting pollinators and animals for seed dispersal and for mitigating abiotic stress (Georgiev et al. 2008; Polturak and Aharoni 2018; Stintzing and Carle 2004). The function of betalains in response to biotic stress is less described; however, the few studies available describe betalain production to be beneficial for defense against fungal and bacterial pathogens (Polturak and Aharoni 2018). Tobacco plants producing red betalain pigments exhibited increased resistance toward the gray mold pathogen, Botrytis cinerea (Polturak et al. 2017), and it has been suggested that betalains evolved in plants for their antifungal properties (Brockington et al. 2011). Further studies are warranted to elucidate the genetic basis of resistance and any associations with betalain production in response to specific pathogens, such as $P$. betae.

\begin{tabular}{|c|c|c|c|c|c|c|c|c|}
\hline \multicolumn{9}{|c|}{$\begin{array}{c}\text { TABLE } 3 \\
\text { Disease progression of Phoma leaf spot epidemics caused by Phoma betae in table beet cultivars Rhonda and Falcon at Freeville } \\
\text { and Geneva, NY, in } 2018\end{array}$} \\
\hline Cultivar, field & Best fitw & Slope & Intercept & $R^{* 2 x}$ & RMSE $^{\mathbf{y}}$ & F statistic & $\boldsymbol{P}$ & CV $(\%)^{z}$ \\
\hline Rhonda, Geneva & Gompertz & 0.041 & -1.78 & 0.92 & 0.18 & 65.85 & 0.0002 & -23.71 \\
\hline Rhonda, Freeville & Gompertz & 0.075 & -1.64 & 0.96 & 0.19 & 45.61 & 0.0066 & -48.36 \\
\hline Falcon, Geneva & Gompertz & 0.041 & -2.0 & 0.97 & 0.11 & 162.53 & $<0.0001$ & -11.83 \\
\hline
\end{tabular}

${ }^{\mathrm{w}}$ Best fit from comparisons between the exponential, monomolecular, logistic, and Gompertz models.

${ }^{\mathrm{x}}$ Back-transformed $R^{* 2}$.

${ }^{\mathrm{y}}$ Root mean square error.

${ }^{\mathrm{z}}$ Coefficient of variation.

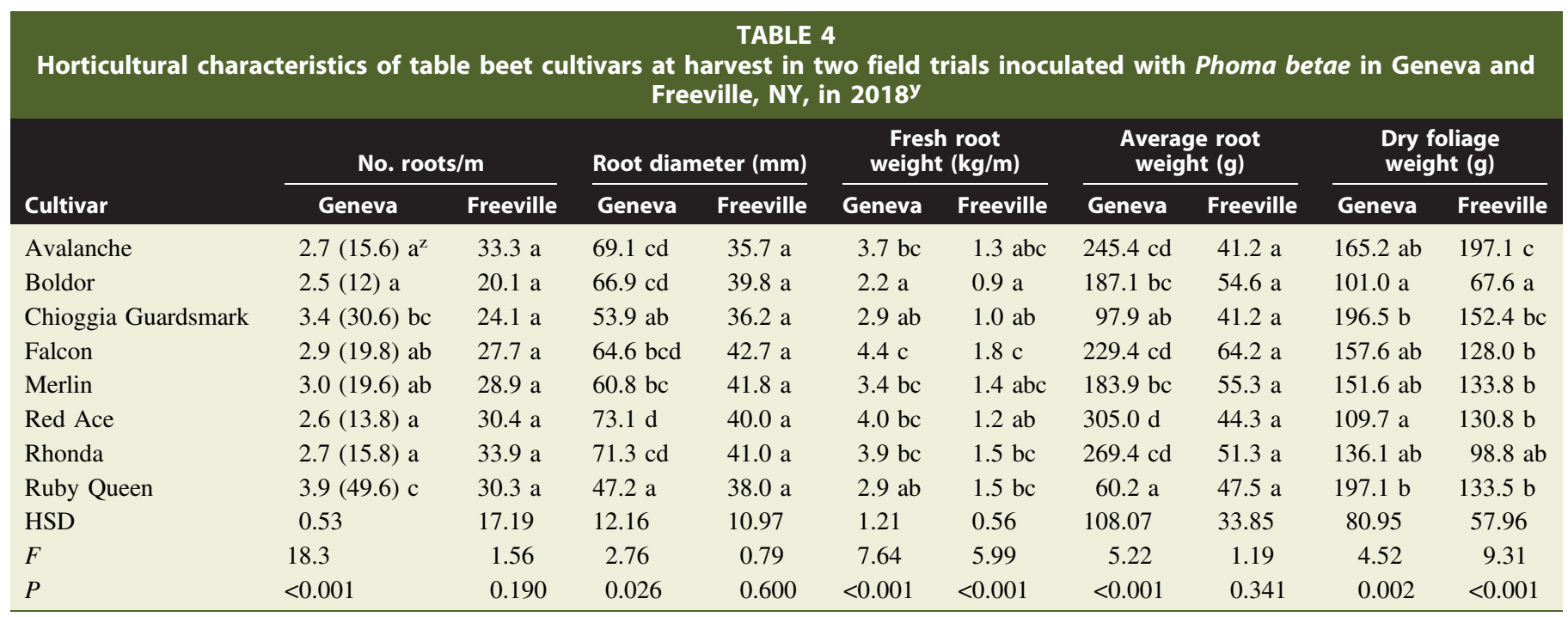

y Trials were harvested at 91 and 86 days after planting in Geneva and Freeville, respectively. Nontransformed values in parentheses.

${ }^{\mathrm{z}}$ Values given are the means of five replicates harvested from a 1-m transect in each plot. Means followed by the same letter in a column are not statistically different using the Tukey-Kramer honestly significant difference (HSD) $(P \leq 0.05)$. 
Temporal progress of PLS epidemics in Rhonda and Falcon were best fit to a Gompertz model, suggestive of a polycyclic disease. Similar temporal patterns have been depicted for comparable pathosystems including ray blight of pyrethrum caused by Phoma ligulicola (syn. Stagonosporopsis tanaceti) (Pethybridge et al. 2005) and disease caused by Corynespora cassiicola on cotton (Bowen et al. 2018). Foundational knowledge of the biology of $P$. betae also supports a polycyclic epidemic in table beet (Harveson et al. 2009). Polycyclic diseases can be managed by reducing the rate $(d y / d t)$ of disease progression (Madden et al. 2007). Selection of table beet cultivars that are less susceptible to PLS or other inseason tactics (i.e., fungicides) are important to achieve this goal.

This study demonstrated that in-row plant density significantly differed among cultivars and corroborated its relationship with table beet root characteristics, including diameter and weight. This finding confirms previous studies that higher plant density is positively correlated with root number but negatively correlated with root size and weight (Benjamin and Bell 1985; Kikkert et al. 2010; Mack 1979). At Geneva, Ruby Queen produced the highest number of roots per row meter; however, Ruby Queen also produced smaller roots on average than other cultivars. Most yield components were similar among non-red and red cultivars. In Geneva, root number did not significantly differ between Avalanche (white), Boldor (yellow), Red Ace (red), and Rhonda (red). Additionally, root diameter did not significantly differ between Avalanche (white), Boldor (yellow), Falcon (red), Red Ace (red), and Rhonda (red). In Freeville, there were no significant differences among cultivars in root diameter and individual root weight. Cultivars that were less susceptible to PLS did not necessarily have higher yields. In both trials, there were no significant differences in foliage among six table beet cultivars, including red and non-red representatives. Although Boldor was less susceptible to PLS, root and foliage biomass was significantly lower compared with other cultivars at both locations. Additional research to disentangle relationships between PLS and crop loss is essential to fully understand the effects of this disease on productivity and profitability. Cultivar evaluation in other locations would also be beneficial, because disease susceptibility and horticultural characteristics may vary with microclimate and local pathogen populations.

This study quantified differences among eight table beet cultivars in PLS susceptibility and horticultural characteristics in NY. Nonred cultivars were less susceptible than red cultivars to PLS. Of the red cultivars in this study, Rhonda was most susceptible to PLS. The PLS epidemics in Falcon and Rhonda were best described by Gompertz models typical of a polycyclic epidemic. Further studies are needed to elucidate associations between specific betalains and their role in susceptibility to important fungal pathogens. To design a comprehensive disease management program for PLS, information on efficacy of conventional and Organic Material Review Institute-approved fungicides is also essential.

\section{Acknowledgments}

This study formed a portion of research submitted in partial fulfillment of the requirements for a Master of Science degree for L. B. Koenick. We thank Carol Bowden, Audrey Klein, Sean Murphy, Matt Schwarzkopf, and Alex Silva (listed alphabetically by surname) for excellent technical support.

\section{Literature Cited}

Abawi, G. S., Crosier, D. C., Cobb, A. C., and Becker, R. F. 1986. Root rot of table beets in New York State. New York's Food and Life Sciences Bulletin, No. 115. New York State Agricultural Experiment Station, Geneva, NY.
Ariyawansa, H. A., Thambugala, K. M., Manamgoda, D. S., Jayawardena, R., Camporesi, E., Boonmee, S., Wanasinghe, D. N., Phookamsak, R., Hongsanan, S., Singtripop, C., Chukeatirote, E., Kang, J.-C., Jones, E. B. G., and Hyde, K. D. 2015. Towards a natural classification and backbone tree for Pleosporaceae. Fungal Divers. 71:85-139.

Atkinson, A. C. 1987. Plots, Transformations, and Regression: An Introduction to Graphical Methods of Diagnostic Regression Analysis. Oxford University Press, Oxford, U.K

Bates, D., Mächler, M., Bolker, B., and Walker, S. 2015. Fitting linear mixedeffects models using lme4. J. Stat. Softw. 67:1-48.

Benjamin, L. R., and Bell, N. 1985. The influence of seed type and plant density on variation in plant size of red beet (Beta vulgaris L.) crops. J. Agric. Sci. 105:563-571.

Bowen, K. L., Hagan, A. K., Pegues, M., Jones, J., and Miller, H. B. 2018. Epidemics and yield losses due to Corynespora cassiicola on cotton. Plant Dis. 102:2494-2499.

Brent, K. J., and Hollomon, D. W. 2007. Fungicide Resistance in Crop Pathogens: How Can It Be Managed? FRAC Monograph No. 1, 2nd revised edition. Fungicide Resistance Action Committee, Bristol, U.K.

Brockington, S. F., Walker, R. H., Glover, B. J., Soltis, P. S., and Soltis, D. E. 2011. Complex pigment evolution in the Caryophyllales. New Phytol. 190: 854-864.

Bugbee, W. M. 1979. Pleospora bjoerlingii in the USA. Phytopathology 69: 277-278.

Bugbee, W. M. 1982. Storage rot of sugar beet. Plant Dis. 66:871-873.

Bugbee, W. M., and Soine, O. C. 1974. Survival of Phoma betae in soil. Phytopathology 64:1258-1260.

Burdon, J. J., and Chilvers, G. A. 1982. Host density as a factor in plant disease ecology. Annu. Rev. Phytopathol. 20:143-166.

Clark, B. E., Peck, N. H., Becker, R. F., and Kline, D. B. 1967. Predicting Field Stands of Table Beets. Seed Research Circular No. 2. New York State Agricultural Experiment Station, Cornell University.

Clifford, T., Constantinou, C. M., Keane, K. M., West, D. J., Howatson, G., and Stevenson, E. J. 2017. The plasma bioavailability of nitrate and betanin from Beta vulgaris rubra in humans. Eur. J. Nutr. 56:1245-1254.

Cook, R. D., and Weisberg, S. 1982. Residuals and Influence in Regression. Chapman and Hall, New York, NY.

De Mendiburu, F. 2017. agricolae: Statistical procedures for agricultural research. https://cran.r-project.org/web/packages/agricolae/index.html.

Edson, H. A. 1915. Seedling diseases of sugar beets and their relation to root-rot and crown-rot. J. Agric. Res. 4:135-168.

Fox, J., and Weisberg, S. 2011. An R Companion to Applied Regression, 2nd Ed. SAGE Publications, Thousand Oaks, CA.

Georgiev, V., Ilieva, M., Bley, T., and Pavlov, A. 2008. Betalain production in plant in vitro systems. Acta Physiol. Plant. 30:581-593.

Goldman, I. L., and Navazio, J. P. 2003. History and breeding of table beet in the United States. Plant Breed. Rev. 22:357-388.

Goldman, I. L., and Navazio, J. P. 2008. Table beet. Pages 219-238 in: Vegetables I: Asteraceae, Brassicaceae, Chenopodicaceae, and Cucurbitaceae. Handbook of Plant Breeding. J. Prohens and F. Nuez, eds. Springer, New York, NY.

Harveson, R. M., Hanson, L. E., and Hein, G. L. 2009. Compendium of Beet Diseases and Pests, 2nd Ed. APS Press, St. Paul, MN.

Herr, L. J. 1971. Hot water treatment for elimination of seed-borne Phoma betae and other microbial contaminants from sugar beet seed. J. Am. Soc. Sugar Beet Technol. 16:568-574.

Jeffers, S. 2015. PROTOCOL 07-11.1: V8 agar (V8A) or broth. Laboratory Protocols for Phytophthora Species. K. L. Ivers, ed. APS Press, St. Paul, MN.

Jeger, M. J. 2004. Analysis of disease progress as a basis for evaluating disease management practices. Annu. Rev. Phytopathol. 42:61-82.

Kikkert, J. R., Reiners, S., and Gugino, B. K. 2010. Row width, population density, and harvest date effects on marketable yield of table beet. HortTechnology 20: 560-567.

Koenick, L. B., Vaghefi, N., Knight, N. L., du Toit, L. J., and Pethybridge, S. J. 2019. Genetic diversity and differentiation in Phoma betae populations on table beet in New York and Washington States. Plant Dis. 103. doi: 10.1094/ PDIS-09-18-1675-RE.

Leach, L. D., and MacDonald, J. D. 1976. Seed-borne Phoma betae as influenced by area of sugar beet production, seed processing and fungicidal seed treatments. J. Am. Soc. Sugar Beet Technol. 19:4-15.

Lenth, R., Singmann, H., Love, J., Buerkner, P., and Herve, M. 2018. emmeans: Estimated marginal means, aka least-squares means. https://cran.r-project. org/web/packages/emmeans/index.html.

Mack, H. J. 1979. Effects of row spacings, fertilizers, and harvest dates on table beets. J. Am. Soc. Hortic. Sci. 104:717-720.

Madden, L. V., Hughes, G., and Van den Bosch, F. 2007. The Study of Plant Disease Epidemics. APS Press, St. Paul, MN. 
Mangan, A. 1971. A new method for the detection of Pleospora bjoerlingii infection of sugar beet seed. Trans. Br. Mycol. Soc. 57:169-172.

Mangiafico, S. 2018. rcompanion: Functions to support extension education program evaluation. https://cran.r-project.org/web/packages/rcompanion/index.html.

Miller, P. 1955. V-8 juice agar as a general-purpose medium for fungi and bacteria. Phytopathology 45:461-462.

Miller, R. G. J. 1981. Simultaneous Statistical Inference, 2nd Ed. SpringerVerlag, New York, NY.

Monte, E., and García-Acha, I. 1988. Germination of conidia in Phoma betae. Trans. Br. Mycol. Soc. 91:133-139.

Navazio, J., Colley, M., and Zyskowski, J. 2010. Principles and Practices of Organic Beet Seed Production in the Pacific Northwest. https://seedalliance.org/ publications/principles-practices-organic-beet-seed-production-pacificnorthwest/. Organic Seed Alliance, Port Townsend, WA

Northeast Regional Climate Center. 2018. CLIMOD 2. Monthly summarized data. http://climod2.nrcc.cornell.edu/. Northeast Regional Climate Center, Geneva, NY.

Pethybridge, S., Kikkert, J., Hanson, L., and Nelson, S. 2018. Challenges and prospects for building resilient disease management strategies and tactics for the New York table beet industry. Agronomy (Basel) 8:112.

Pethybridge, S. J., Esker, P., Hay, F., Wilson, C., and Nutter, F. W. 2005. Spatiotemporal description of epidemics caused by Phoma ligulicola in Tasmanian pyrethrum fields. Phytopathology 95:648-658.

Pethybridge, S. J., Vaghefi, N., and Kikkert, J. R. 2017a. Horticultural characteristics and susceptibility of table beet cultivars to Cercospora leaf spot in New York. HortTechnology 27:530-538.

Pethybridge, S. J., Vaghefi, N., and Kikkert, J. R. 2017b. Management of Cercospora leaf spot in conventional and organic table beet production. Plant Dis. 101:1642-1651.

Polturak, G., and Aharoni, A. 2018. "La Vie en Rose": Biosynthesis, sources, and applications of betalain pigments. Mol. Plant 11:7-22.

Polturak, G., Grossman, N., Vela-Corcia, D., Dong, Y., Nudel, A., Pliner, M., Levy, M., Rogachev, I., and Aharoni, A. 2017. Engineered gray mold resistance, antioxidant capacity, and pigmentation in betalain-producing crops and ornamentals. Proc. Natl. Acad. Sci. 114:9062-9067.

Pool, V. W., and McKay, M. B. 1915. Phoma betae on the leaves of sugar beet. J. Agric. Res. 4:169-177.

R Core Team. 2017. R: A language and environment for statistical computing. Foundation for Statistical Computing, Vienna, Austria. https://www.Rproject.org/.

Rife, T. W., and Poland, J. A. 2014. Field Book: An open-source application for field data collection on Android. Crop Sci. 54:1624-1627.

Shah, D. A., and Stivers-Young, L. 2004. Factors associated with decay in table beets identified by a statistical analysis of grower and processor records. HortTechnology 14:25-29.

Shapiro, S. S., and Wilk, M. B. 1965. An analysis of variance test for normality (complete samples). Biometrika 52:591-611.

Simko, I., and Piepho, H.-P. 2012. The area under the disease progress stairs: Calculation, advantage, and application. Phytopathology 102:381-389.

Smith, G. A., and Martin, S. S. 1978. Differential response of sugarbeet cultivars to Cercospora leaf spot disease. Crop Sci. 18:39-42.

Stintzing, F. C., and Carle, R. 2004. Functional properties of anthocyanins and betalains in plants, food, and in human nutrition. Trends Food Sci. Technol. 15:19-38.

U.S. Department of Agriculture (USDA). 2017. United States standards for grades of canned beets. Federal Register 81 FR 93572.

U.S. Department of Agriculture-NASS (USDA-NASS). 2012. 2012 Census of Agriculture. https://www.nass.usda.gov/Publications/AgCensus/2012/Full_ Report/Volume_1,_Chapter_1_US/.

Vaghefi, N., Hay, F. S., Kikkert, J. R., and Pethybridge, S. J. 2016. Genotypic diversity and resistance to azoxystrobin of Cercospora beticola on processing table beet in New York. Plant Dis. 100:1466-1473.

Vanderplank, J. E. 1963. Plant Diseases: Epidemics and Control. Academic Press, New York, NY.

Wickham, H. 2016. ggplot2: Elegant Graphics for Data Analysis, 2nd Ed. Springer-Verlag, New York, NY. 